\section{Comparative Analys is of Biofilm Formation on Materials Used for the Fabrication of Implant-Supported Prostheses}

\author{
Ramtin Sadid-Zadeh ${ }^{1 \oplus}$, Jeffrey Willis ${ }^{\circledR}{ }^{\circledR}$, Gyula Forgo ${ }^{2}{ }^{\circledR}$, Violet Haraszthy ${ }^{2}{ }^{\circledR}$
}

\author{
'Department of Restorative Dentistry, \\ University at Buffalo School of \\ Dental Medicine, Buffalo, NY \\ ${ }^{2}$ Department of Prosthodontics, \\ University at Buffalo School of \\ Dental Medicine, Buffalo, NY \\ Correspondence: Ramtin Sadid- \\ Zadeh, 3435 Main Street, 222E \\ Squire Hall, 14214-8006 Buffalo, \\ NY, USA. Tel:+716-829-2862. \\ e-mail: rsadidza@buffalo.edu
}

Key Words: biofilm formation, implant dentistry, zirconia, titanium, poly methyl methacrylate, peri-implantitis.

\section{Introduction}

The physical and chemical traits, including surface free energy, roughness, and chemical composition of a material determine how robustly bacteria adhere to that substrate (1-3). Given that bacterial biofilms, which form on restorative materials used in dental prostheses, have been strongly linked to the development of peri-mucositis and peri-implantitis, an understanding of the factors that promote bacterial adherence and growth is essential to provide positive patient outcomes. Therefore, in addition to considering the durability and esthetic qualities of a restorative material, identifying factors that increase the adherence of biofilm to a prosthesis may impact the long-term success of dental implants (4). For example, in vitro studies show that, when comparing multiple factors, an increased surface roughness has the greatest positive correlation with the amount of bacterial colonization and in determining the strain composition of dental biofilms (5-9)

Peri-mucositis and peri-implantitis associated with dental implants have similar characteristics with destructive periodontal diseases that occur around natural dentition. Both diseases are multifactorial and strongly correlated with the presence of gram-negative anaerobic bacteria in the microbiota surrounding the prostheses or natural dentition. These bacterial pathogens include Porphyromonas gingivalis, Treponema denticola, Tannerella forsythia, Fusobacterium species, and Prevotella intermedia (10-17); additionally, the presence of Aggregatibacter actinomycetemcomitans, Staphylococcus aureus, and Candida albicans has also been reported at sites of periimplantitis (18-22).

The use of zirconia abutments and dental implants has significantly reduced irritation at the interface between the prosthesis and the peri-implant soft tissue (23). Furthermore, multiple in vivo and in vitro investigations of the soft tissue response around zirconia prostheses revealed a better healing response and reduced plaque adhesion on prostheses fabricated from zirconia compared to those composed of titanium (24-28). However, dental practitioners restore implants with variety of materials, including zirconia and other dental ceramic, heat-cured polymethyl methacrylate, titanium and other metal alloys, or a combination of these materials (29-31). While durability and esthetics are important factors when choosing a material for implant supported prostheses, selecting restorative materials that are refractory to bacterial colonization will decrease the incidence of peri-implantitis.

This study compared both the surface roughness $\left(R_{a}\right)$ of 
materials frequently used for the fabrication of definitive implant-supported prosthesis and the adherence of gramnegative anaerobic bacteria associated with peri-implantitis to these materials.

\section{Material and Methods}

Twenty discs using heat-cured polymethyl methacrylate (PMMA) (Lucitone 199; Dentsply; York, PA, USA), yttria tetragonal zirconia polycrystal (Y-TZP) (Zenostar; Ivoclar Vivadent; Amherst, NY, USA), or commercially pure titanium (CP-Ti) (Ti-6Al-4V, Staub Inc; Hamburg, NY, USA) were fabricated, for a total of sixty discs. All specimens were polished following the standard protocol described in Table 1 for the corresponding material. Next, to simulate clinical circumstances, all specimens were hand polished using an electric handpiece (NSKX20L 1:1; Brasseler USA; Savannah, GA, USA); polishing burs were used at 10,000 RPM.

Five discs fabricated from each material described above were chosen randomly for surface roughness assessment. After the polishing procedure, discs were placed in an ultrasonic cleaner containing distilled water for five minutes. Surface roughness (Ra) was measured by applying a non-contact profilometer (NPFLEX, Bruker, UK) to each specimen at four random regions of $1 \mathrm{~mm}$ by $1 \mathrm{~mm}$ in size. The surface roughness for each disc was determined by the averaging the Ra values found for each of the four measured regions.

After the assessment of surface roughness, discs were placed in an ultrasonic cleaner containing isopropyl alcohol for $10 \mathrm{~min}$ to remove debris. Specimens were then sterilized with ethylene oxide as specified by ISO 11135:2014 requirements for medical devices. Five strains of Gram-negative bacteria frequently associated with peri-implantitis (24), A. actinomycetemcomitans (Aa), C. albicans (Ca), P. gingivalis $(\mathrm{Pg})$, P. intermedia (Pi), and T. forsythia (Tf) were used in this study. Cryopreserved bacterial strains were used to inoculate non-selective blood agar media and incubated under anaerobic conditions for $72 \mathrm{~h}$ at $37^{\circ} \mathrm{C}$ to allow bacterial growth. A bacterial colony from each strain was then used to inoculate brain-heart infusion (BHI) media and cultures were grown to an optical density (OD) of 0.5 ; the optical density was measured using a spectrophotometer (SmartSpec ${ }^{\text {TM }} 3000$, BIO-RAD; Hercules, CA, USA). The bacterial cultures were diluted ten-fold with $\mathrm{BHI}$, dispensed onto the prepared Y-TZP, PMMA, or CP-Ti discs, and then incubated for $72 \mathrm{~h}$ under anaerobic conditions.

Next, to quantify the amount of bacterial growth on each disc, the number of colony-forming units were determined. Following incubation, discs were gently rinsed with distilled water to remove non-adherent bacteria, placed in an Eppendorf tube containing $1 \mathrm{~mL}$ volume of sterile Ringer's solution, and held on a vortex mixer for 60 $s$ to remove adherent bacteria from the discs. Using a spiral plater (Autoplate ${ }^{\mathrm{TM}} 4000$, Spiral Biotech; Norwood, MA), petri dishes containing non-selective blood agar media were inoculated with undiluted $50 \mu \mathrm{L}$ aliquots from each sample; plates were then incubated for $72 \mathrm{~h}$ at $37^{\circ} \mathrm{C}$ to allow bacterial growth. Bacterial colonies were counted and reported as $\mathrm{CFU} / \mathrm{mL}$ according to manufacturer's instructions (Autoplate ${ }^{\mathrm{TM}} 4000$ ).

One-way ANOVA was followed by Tukey HSD, GameHowell, or multiple comparison tests, which were used to statistically analyze the influence of material choice and surface roughness values on the amount of bacterial colonization, with statistical significance at $a=0.05$.

\section{Results}

For each material used, the mean surface roughness $\left(R_{a}\right)$ values and standard deviations are presented in Table 2. Discs fabricated from either heat-cured PMMA or CP-Ti had significantly smaller $R_{a}$ values than $Y-T Z P$ discs $(p<0.05)$. However, there was no significant difference between the $R_{a}$ values found for PMMA and CP-Ti discs ( $\left.p>0.05\right)$.

Table 3 shows the average number of colony forming units (CFU/mL) for each bacterial strain and the corresponding material on which growth occurred. For $\mathrm{Pi}_{\text {, }}$ $\mathrm{Pg}$, and $\mathrm{Aa}$, the equal variance assumption was not met $(p=0.05)$; therefore, the Brown-Forsythe robust one-way ANOVA was used, followed by the Games-Howell test procedure. The equal variance assumption was met for Ca and Tf; therefore, results from the standard one-way

Table 1. Restorative materials and polishing protocols

\begin{tabular}{|c|c|}
\hline Material & Polishing protocol \\
\hline $\mathrm{CP}-\mathrm{Ti}$ & $\begin{array}{l}\text { Machined CP Ti discs were polished for } 20 \mathrm{~s} \text { using a metal polishing kit with coarse- } \\
\text { to-fine wheels (Airflex, Brasseler USA, Savannah, GA, USA) }\end{array}$ \\
\hline Y-TZP & $\begin{array}{l}\text { Milled Y-TZP discs were polished for } 20 \mathrm{~s} \text { using a Y-TZP polishing kit with coarse- } \\
\text { to-fine wheels (Dialite ZR, Brasseler USA, Savannah, GA, USA) }\end{array}$ \\
\hline PMMA & $\begin{array}{l}\text { 1: Processed PMMA discs were finished using 200-600 grit sandpaper: 2: Pumice slurry polishing for } 20 \mathrm{~s} ; 3 \text { : Acrylic } \\
\text { polishing system for } 20 \mathrm{~s} \text { (medium to fine grit - Provisional Polisher, Brasseler USA, Savannah, GA, USA) }\end{array}$ \\
\hline
\end{tabular}

PMMA=Heat-cured polymethyl methacrylate; $\mathrm{Y}-\mathrm{TZP}=\mathrm{Yttria}$ tetragonal zirconia polycrystal, $\mathrm{CP}-\mathrm{Ti}=$ Commercially pure titanium. 
ANOVA and the Tukey multiple comparison procedure were reported.

Results from a Brown-Forsythe robust one-way ANOVA indicated a significant difference in the growth of $\mathrm{Pi}(\mathrm{F} 2$, 4.68=11.63, $p=0.015), \operatorname{Pg}(F 2,4.99=189.24, p<0.005)$, and Aa $(F 2,5.79=731.53, p<0.005)$ by restorative material. For $\mathrm{Pi}$, multiple comparisons test indicated a trend towards significance for the difference in bacterial growth on Y-TZP compared to PMMA ( $p=0.055)$, and on PMMA compared to $\mathrm{CP}-\mathrm{Ti}(\mathrm{p}=0.053)$; however, there was no significant difference in the amount of growth on CP-Ti compared to Y-TZP. For Pi, the highest mean cell count was found for PMMA, followed by Y-TZP and CP-Ti. For Pg, multiple comparisons test indicated a significant difference among all mean pairs $(p<0.005)$. For $P g$, the greatest number of colony-forming units was found for PMMA, followed by CP-Ti and Y-TZP, respectively. For $\mathrm{Aa}$, a post hoc multiple comparisons indicated a significant difference between bacterial growth on Y-TZP compared to both PMMA $(p<0.005)$ and CP-Ti $(p<0.005)$; however, there was no significant difference in the amount of growth on PMMA compared to CP-Ti. For Aa, the highest mean cell count was found for PMMA, followed by CP-Ti and Y-TZP, respectively (Table 3).

One-way ANOVA results indicated a significant

Table 2. Mean \pm SD surface roughness $\left(R_{a}\right)$ in $\mu$ m for each restorative material

\begin{tabular}{lc}
\hline Group & $\mathrm{R}_{\mathrm{a}}(\mu \mathrm{m})$ \\
\hline PMMA & $218 \pm 87^{\mathrm{a}}$ \\
Y-TZP & $360 \pm 40^{\mathrm{b}}$ \\
CP-Ti & $170 \pm 22^{\mathrm{a}}$ \\
\hline
\end{tabular}

PMMA=Heat-cured polymethyl methacrylate; $Y-T Z P=Y$ ttria tetragonal zirconia polycrystal, $\mathrm{CP}-\mathrm{Ti}=\mathrm{Commercially} \mathrm{pure} \mathrm{titanium.} \mathrm{Different}$ letters indicate statistically significant difference $(\mathrm{p}<0.05)$.

Table 3 Mean \pm SD number of colony forming units per milliliter for each bacterial strain adhered to PMMA, Y-TZP, or CP-Ti discs

\begin{tabular}{lccc}
\hline Bacterial strain & PMMA & Y-TZP & CP-Ti \\
\hline $\mathrm{Pi}$ & $235185 \pm 54328$ & $134722 \pm 29333$ & $125000 \pm 5345.83$ \\
$\mathrm{Pg}$ & $174074 \pm 13940.23$ & $46401 \pm 6779$ & $107407 \pm 4276$ \\
$\mathrm{Aa}$ & $8333333 \pm 427666$ & $1079545 \pm 196823$ & $7777777 \pm 213833$ \\
$\mathrm{Tf}$ & $109722 \pm 20697$ & $22443 \pm 4233$ & $30397 \pm 5756$ \\
$\mathrm{Ca}$ & $17897 \pm 1429$ & $14015 \pm 2531$ & $26325 \pm 4335$ \\
\hline
\end{tabular}

Pi=Prevotella intermedia; $P g=$ Porphyromonas gingivalis; Aa=Aggregatibacter actinomycetemcomitans; $\mathrm{Tf}=$ Tannerella forsythia $; \mathrm{Ca}=$ Candida albicans; $\mathrm{PMMA}=$ Heatcured polymethyl methacrylate; $\mathrm{Y}-\mathrm{TZP}=$ Yttria tetragonal zirconia polycrystal; $\mathrm{CP}-$ $\mathrm{Ti}=$ Commercially pure titanium. difference in the growth of Tf growth $(F 2,9=58.29, p<0.005)$ compared with $\mathrm{Ca}(\mathrm{F} 2,9=17.44, \mathrm{p}=0.001)$ by restorative materials. Multiple comparisons test indicated a significant difference between the amount of Tf found on PMMA compared to both Y-TZP $(p<0.005)$ and CP-Ti $(p<0.005)$; however, there was no significant difference between the amount of growth on Y-TZP compared to CP-Ti. For Tf, the highest mean cell count was found for PMMA, followed by CP-Ti and Y-TZP, respectively. For $\mathrm{Ca}$, Multiple comparisons test indicated a significant difference between the amount of bacterial growth on CP-Ti compared to both PMMA $(p=0.008)$ and Y-TZP $(p=0.001)$; however, there was no significant difference between PMMA and Y-TZP. For $\mathrm{Ca}$, the highest mean cell count was found for CP-Ti, followed by PMMA and Y-TZP, respectively (Table 3).

\section{Discussion}

This study evaluated the amount of bacterial colonization on three restorative dental materials routinely used for definitive implant-supported prostheses. Studies regarding bacterial adhesion to dental materials have shown that there is a direct positive correlation between the surface roughness of a substrate and bacterial adhesion to that material $(25,26,32)$. In this study, Y-TZP surface roughness was significantly higher than $\mathrm{CP}-\mathrm{Ti}$; however, Y-TZP discs exhibited either a similar, or significantly less $(p<0.05)$, amount of bacterial colonization compared to CP-Ti discs. In addition to the surface roughness, there is a positive correlation between the wettability of a material and bacterial colonization (32-34) Therefore, while Y-TZP has a higher surface roughness than CP-Ti, the lower wettability of Y-TZP compared to CP-Ti may have led to the comparable level of bacterial colonization on these materials that was observed in this study (35).

This study found that Y-TZP discs had a greater surface roughness than PMMA discs, but this difference was not statistically significance. However, bacterial colonization was significantly higher for PMMA discs as compared to Y-TZP discs. This result may be due to the surface wettability or porous nature of PMMA compared to Y-TZP (35).

Van Brakel et al. (33) evaluated early bacterial colonization of zirconia and titanium abutments; however, no statistically significant difference was observed in the growth of several indicator bacteria, including A. actinomycetemcomitans, P. gingivalis, P.intermedia, and $T$. forsythia, between the zirconia and titanium abutments. Similarly, in a study that examined colonization by $A$. actinomycetemcomitans and P. gingivalis, Salihoglu et al. (36) found that Y-TZP discs 
had similar, or significantly less, bacterial colonization levels as compared to CP-Ti discs. The difference in our results may be a result of differences in the surface roughness of the specimens; Van Brakel et al. (33) evaluated discs with considerably larger Ra values (210-236 nm), while the Ra values in this study were much lower. However, the Ra value was not reported in the study performed by Salihoglu et al (36).

Although there are studies evaluating materials for implant-supported crowns; previous studies have not evaluated colonization of PMMA compared to Y-TZP and $\mathrm{CP}-\mathrm{Ti}$ by bacteria associated with peri-implantitis. These materials are used individually, or in combination, for the fabrication of implant-supported prosthesis. This study found a higher level of bacterial colonization on PMMA discs as compared to CP-Ti and Y-TZP discs. This result may be due to the porous nature of heat-cured PMMA and the associated surface energy (37).

The outcome of this study suggests that implantsupported prosthesis fabricated from Y-TZP with or without CP-Ti might be a superior prosthetic option for fewer bacteria colonization. However, future studies should include additional materials such as CAD-CAM fabricated PMMA.

The present study shows that bacteria colonize Y-TZP to a similar, or lesser, extent compared to CP-Ti; these results suggest that use of Y-TZP restorations may result in a similar, or fewer, number of peri-mucositis and periimplantitis cases. Additionally, as compared to restorations fabricated from Y-TZP and CP-Ti, our results suggest that the use of heat-cured PMMA in dental prostheses may lead to an increased colonization by bacteria associated with peri-mucositis and peri-implantitis.

\section{Resumo}

0 objetivo deste estudo foi comparar a formação de biofilme em materiais utilizados na confecção de próteses dentárias implantossuportadas. Vinte discos ( $D=15 \mathrm{~mm}, \mathrm{H}=3 \mathrm{~mm}$ ) foram confeccionados com um dos seguintes materiais restauradores: zircônia tetragonal policristalina estabilizada por itrio (Y-TZP); titânio comercialmente puro (CP-Ti); ou polimetilmetacrilato (PMMA). As amostras foram polidas seguindo protocolos padrão. Um perfilômetro sem contato (NPFLEX, Bruker, UK) foi usado para avaliar a rugosidade da superfície de cada disco; os resultados foram relatados como $R_{a}(\mu \mathrm{m})$. Cinco cepas de bactérias Gram-negativas freqüentemente associadas a peri-implantite, Aggregatibacter actinomycetemcomitans, Candida. albicans, Porphyromonas gingivalis, Prevotella intermedia e Tannerella forsythia, foram cultivadas em discos polidos à mão feitos de PMMA, Y-TZP ou CP-Ti para comparar a formação de biofilme em cada tipo de material. 0 s resultados foram relatados como unidades formadoras de colônias por mililitro (UFC/mL). Análise de variância a um fator e testes post hoc foram usados para comparar a rugosidade da superficie e a colonização bacteriana nos respectivos materiais. A significância estatística foi estabelecida em $a=0,05$. Os discos feitos de $Y$-TZP tiveram um valor $R_{a}$ significativamente mais alto $(350 \pm 30 \mu \mathrm{m})$ do que os discos de PMMA ou $\mathrm{CP}-\mathrm{Ti}$. Os discos fabricados com Y-TZP e CP-Ti podem apresentar menor colonização por bactérias associadas à perimucosite e peri-implantite. Considerando 0 Y-TZP e CP-Ti são materiais indicados para a confecção de próteses implantossuportadas, considerando a formação de biofilme.

\section{References}

1. Hannig M, Dobert A, Stigler R, Muller U, Prokhorova SA. Initial salivary pellicle formation on solid substrates studied by AFM. J Nanosci Nanotechnol 2004;4:532-538.

2. Quirynen $M$, Bollen $C M$. The influence of surface roughness and surface-free energy on supra- and subgingival plaque formation in man. A review of the literature. J Clin Periodontol 1995;22:1-14.

3. Scheie AA. Mechanisms of dental plaque formation. Adv Dent Res 1994;8:246-253.

4. Groessner-Schreiber B, Hannig M, Dück A, Griepentrog M, Wenderoth DF. Do different implant surfaces exposed in the oral cavity of humans show different biofilm compositions and activities? Eur J Oral Sci 2004;112:516-522.

5. Zortuk M, Kesim S, Kaya E. Bacterial adhesion of porphyromonas Gingivalis. Dent Res J 2010;7:35-40.

6. Bollen CM, Papaioanno W, Van Eldere J, Schepers E, Quirynen M, van Steenberghe D. The influence of abutment surface roughness on plaque accumulation and peri-implant mucositis. Clin Oral Implants Res 1996;7:201-211.

7. Bollen CM, Papaioanno W, Van Eldere J, Schepers E, Quirynen M, van Steenberghe D. The influence of titanium abutment surface roughness on plaque accumulation and gingivitis: Short-term observations. Int J Oral Maxillofac Implants 1996;11:169-178.

8. Lindhe J, Berglundh T, Ericsson I, Liljenberg B, Marinello C. Experimental breakdown of peri-implant and periodontal tis- sues. A study in the beagle dog. Clin Oral Implants Res 1992;3:9-16.

9. Ong ES, Newman HN, Wilson M, Bulman JS. The occurrence of periodontitis-related microorganisms in relation to titanium implants. J Periodontol 1992;63:200-205.

10. Adell R, Lekholm U, Rockler B, Branemark P-I, Lindhe J, Eriksson B, et al. Marginal tissue reactions at osseointegrated titanium fixtures. I. A 3-year longitudinal prospective study. Int J Oral Maxillofac Implants 1986:15:39-52.

11. Bower RC, Radny NR, Wall CD, Henry PJ. Clinical and microscopic findings in edentulous patients 3 years after incorporation of osseointegrated implant-supported bridgework. J Clin Periodontol 1989:16:580-587.

12. Mombelli A, Buser A, Lang NP. Colonization of osseointegrated titanium implants in edentulous patients. Early results. Oral Microbiol Immunol 1988:3:113-120.

13. Mombelli A, Mericske-Stern R. Microbiological features of stable osseointegrated implants used as abutments for overdentures. Clin Oral Implants Res 1990:1:1-7.

14. Mombelli A, Van Oosten MAC, Schurch E, Lang NP. The microbiota associated with successful or failing osseointegrated titanium implants. Oral Microbiol Immunol 1987:2:145-151.

15. Shibli JA, Melo L, Ferrari DS, Figueiredo LC, Faveri M, Feres M. Composition of supra- and subgingival biofilm of subjects with healthy and diseased implants. Clin Oral Implants Res 2008:19:975-982.

16. Socransky SS, Haffajee AD, Cugini MA, Smith $C$, Kent RL Jr. Microbial complexes in subgingival plaque. J Clin Periodontol 1998:25:134-144.

17. Tabanella G, Nowzari H, Slots J. Clinical and microbiological determinants of ailing dental implants. Clin Implant Dent Relat Res 2009:11:24-36.

18. Hultin $M$, Gustafsson $A$, Hallstrom $H$, Johansson LA, Ekfeldt $A$, Klinge B. Microbiological findings and host response in patients with periimplantitis. Clin Oral Implants Res 2002:13:349-358.

19. van Winkelhoff AJ, Wolf JW. Actinobacillus actinomycetemcomitansassociated peri-implantitis in an edentulous patient. A case report. J Clin Periodontol 2000:27:531-535.

20. Alcoforado GA, Rams TE, Feik D, Slots J. Microbial aspects of failing osseointegrated dental implants in humans. J Parodontol 1991:10:1118.

21. Leonhardt A, Renvert $S$, Dahle'n G. Microbial findings at failing implants. Clin Oral Implants Res 1999:10:339-345.

22. Rosenberg ES, Torosian JP, Slots J. Microbial differences in 2 clinically 
distinct types of failures of osseointegrated implants. Clin Oral Implants Res 1991:2:135-144.

23. Mellinghoff J. Quality of the peri-implant soft tissue attachment of zirconia implants-abutments. Z Zahnärztl Implants 2010;26:62-71.

24. Pae A, Lee H, Kim HS, Kwon YD, Woo YH. Attachment and growth behavior of human gingival fibroblasts on titanium and zirconia ceramic surfaces. Biomed Mater 2009;2:025005-025012.

25. Rimondini $L$, Cerroni $L$, Carrassi A, Torricelli P. Bacterial colonization of zirconia ceramic surfaces: An in vitro and in vivo Study. Int J Oral Maxillofac Implants 2002;17:793-798.

26. Scarano A, Piattelli M, Caputi S, Favero GA, Piattelli A. Bacterial adhesion on commercially pure titanium and zirconium oxide discs: An in vivo human study. J. Periodontol 2004;75:292-296.

27. Degidi M, Artese L, Scarano A, Perrotti V, Gehrke P, Piattelli A. Inflammatory infiltrate, microvessel density, nitric oxide synthase expression, vascular endothelial growth factor expression, and proliferative activity in peri-implant soft tissues around titanium and zirconium oxide healing caps. J Periodontol 2006;77:73-80.

28. Größner-Schreiber $B$, Herzog $M$, Hedderich J, Dück $A$, Hannig $M$, Griepentrog M. Focal adhesion contact formation by fibroblasts cultured on surface-modified dental implants: An in vitro study. Clin Oral Implants Res 2006;17:736-745.

29. Bergendal B, Palmqvist S. Laser-welded titanium frameworks for implant-supported fixed prostheses: a 5-year report. Int J Oral Maxillofac Implants 1999;14:69-71.

30. Bozini T, Petridis H, Garefis K, Garefis P. A meta-analysis of prosthodontic complication rates of implant-supported fixed dental prostheses in edentulous patients after an observation period of at least 5 years. Int J Oral Maxillofac Implants 2011;26:304-318.

31. Larsson C, Vult von Steyern P, Nilner K. A prospective study of implant-supported full-arch yttria-stabilized tetragonal Y-TZP polycrystal mandibular fixed dental prostheses: three-year results. Int J Prosthodont 2010;23:364-369.

32. Al-Ahmad A, Wiedmann-Al-Ahmad M, Faust J, Bachle M, Follo $M$, Wolkewitz $\mathrm{M}$, et al. Biofilm formation and composition on different implant materials in vivo. J Biomed Mater Res B Appl Biomater 2010;95:101-109.

33. Van Brakel R, Cune MS, Van Winkelhoff AJ, De Putter C, Verhoeven JW, Van Der Reijden W. Early bacterial colonization and soft tissue health around zirconia and titanium abutments: an in vivo study in man. Clin Oral Implants Res 2011;22:571-577

34. Lima EM, Koo H, Vacca Smith AM, Rosalen PL, Del Bel Cury AA. Adsorption of salivary and serum proteins and bacterial adherence on titanium and zirconia ceramic surfaces. Clin Oral Implants Res 2008;19:780-785.

35. Wassmann $T$, Kreis $S$, Behr $M$, Buergers R. The influence of surface texture and wettability on initial bacterial adhesion on titanium and zirconium oxide dental implants. Int J Implant Dent 2017;3:32.

36. Salihoglu U, Boynuegri D, Engin D, Duman AN, Gokalp P, Balos K. Bacterial adhesion and colonization differences between zirconium oxide and titanium alloys: an in vivo human study. Int J Oral Maxillofac Implants 2011;26:101-107.

37. Arslan M, Murat $\mathrm{S}, \mathrm{Alp} \mathrm{G}$, Zaimoglu A. Evaluation of flexural strength and surface properties of prepolymerized CAD/CAM PMMA-based polymers used for digital 3D complete dentures. Int J Comput Dent 2018;21:31-40. 